\title{
Neural network and index forecasting of the strategies of development of the armed forces of Ukraine depending on their own economic opportunities and encroachments of the states of aggressors
}

\author{
Vasyl Porokhnya ${ }^{1, *}$, and Oleksandr Ostapenko ${ }^{2}$ \\ ${ }^{1}$ Classical Private University, Zaporizhzhia, Ukraine \\ ${ }^{2}$ Taras Shevchenko National University of Kyiv, Kyiv, Ukraine
}

\begin{abstract}
Ukraine has a relative drawback in the economic defense capabilities, which needs to be addressed by raising the indicators of macroeconomic development, innovation, and economic potential, social health of the population of the state, and the support of the Armed Forces of Ukraine, by the state. The estimation of the defense capability of states like Ukraine, Poland, Russia and Turkey is made on the basis of the developed methodological approach to the overall representation of the health of the economies of the states and their defense capabilities using the method of constructing petal diagrams with the definition of their effective areas, which became indicators of economic status and defense capability. The article analyses the dependence of the development level of the countries' economies and the state of development of the armed forces of these countries in the conditions of resource constraints and existing risks on the basis of macroeconomic data and indicators. This article uses the indicators for the determination of the level of defense capability and the data of petal diagrams and the scenario modeling of the development strategies of the Armed Forces of Ukraine with the aim of constructing the most optimal forecast in this area.
\end{abstract}

\section{Introduction}

Ukraine as a State has been suffering from specific political, economic and military oppression from various states throughout its entire existence - from ancient times to the present day. Whether it was its geographical location as the center of Europe or ineffective leadership, Ukraine was always forced to defend its legitimate interests, territorial integrity and independence. Under such conditions, the Armed Forces of Ukraine (the AFU) serve as a key element in the protection of territorial integrity and inviolability of Ukraine, which is entrusted to them by the Constitution of Ukraine.

There is a relative gap in the economic provision of defense capacity in Ukraine. This issue is decided to be solved by the State thought the increase of indicators of macroeconomic development of the innovative economic strength, social health of the population and the support of the Armed Forces.

The end of the second decade of the 21st century on the world map was marked by significant military conflicts between states, in which a militarily stronger state usually neglected interests of adjacent states. Firstly, this is related to Russia with respect to such states as Georgia, Moldova, and Ukraine. Processes on the Balkan axis are still fresh wounds from the gunpowder feeling and not quite a healthy environment for economic development. The Syrian conflict amid the movement of the states in this region towards European markets is related to the economic interests of Russia.

Officially this issue affects every state, although those economies that are under the aegis of NATO (Turkey) or Russia (Belarus, Armenia, etc.) find themselves in a more comfortable position in terms of protection. In this context, Ukraine may rely on its own economic strength that is going through the difficult economic situation for the time being. However, there is its own model of finding a way out of the difficult situation and its own driving force able to bring the country into the worldwide level.

State-to-state relations and ties are disturbances in the model of the Armed Forces development strategy based on domestic economic opportunities and invasion from aggressor states that should be formalized by the projected influences on national security.

\section{Analysis of recent research}

The issues of the strategic behavior development of the armed forces have been recently given considerable attention at the world level. This is related primarily to a new spin in the arms race as well as political and economic instability in the world. Therefore, it is important for every state to have the armed forces development strategy based on domestic economic opportunities and invasion from aggressor states. With

\footnotetext{
Corresponding author: vprhnp76@gmail.com
} 
respect to Ukraine researches and papers of V. Horbulin and A. Kachynskyi deal with the issues of the national security strategic forecasting [1, 3]. The papers of V. Bohdanovych, A. Semenchenko also deal with national security enforcement through the formalization of strategic planning in the area of public administration. [2]. In this context the research notes by O. Reznikova and V. Tsiukalo [4, 5] draws attention. Charles J. Hitch outlined the list of the most relevant decisions made with a focus on security and defense [6]. The defense reform algorithm as a way from the form to content [7] was suggested by A. Hrytsenko in 2006.

However, it should be noted that most of the scientific researches in this area do not usually emphasize the study of the economic and military situation of neighboring states and its development, thus resulting in the unreasonable vision being received on the Armed Forces of Ukraine development strategy as, for example, Ukraine's ability to defend itself.

The question is whether Ukraine is able to reliably defend itself in economic and military terms and which strategy of the AFU development should be chosen based on domestic economic opportunities and invasion from aggressor states. We will try to find the answers in this article.

The purpose of the research is the design of the AFU development strategy based on domestic economic opportunities and invasion from aggressor states.

\section{Presentation of the basic research}

The arms race is the most difficult phase for the economy of any state. This is practically a test of the economic development level for its focus on innovation and competitive ability not only in the defense capacity area but also in the areas shaping the capacity of the economy. The question is, where funding will come from for its own innovative product, or where to borrow money from the available sources in such a way not to worsen the economic health of the state.

In order to design the AFU development strategy based on domestic economic opportunities let us consider the most common indexes and indicators of the State's economic status directly related to the economy capacity and relatively affecting the level of security and defense capacity. To this end let us use statistical data of the economies of the most powerful four states neighboring Ukraine: Ukraine, Poland, Russia, and Turkey. Summary statistics are given in Table 1.

Figure 1 shows a petal diagram with indicators of macroeconomic development, economic potential, social health of the population and support provided to the AFU by the state: Ukraine, Poland, Russia, Turkey, with the areas as the primary characteristic of the State's possibilities to ensure the defense capacity.

In order to get the indicators of economic and military security of the State, it is reasonable to refer to the findings of their estimation by Global Firepower Index, Military Capacity Index and Credit Suisse Institute index and to conduct a comparative analysis of them. The suggested Military Capacity Index built on indicators supplementing other world-famous indexes is focused on covering indicators that characterize the State's ability to restore the defense capacity, Table. 2. Data on indicators of economic and military security of the State are given in Table 3.

Table 1. Data on indicators and indicators of macroeconomic development of states [11-13].

\begin{tabular}{|c|c|c|c|c|}
\hline Indicator Title & \begin{tabular}{|l|} 
Ukraine \\
\end{tabular} & Poland & Russia & Turkey \\
\hline $\begin{array}{l}\text { GDP, billion } \\
\text { USD }\end{array}$ & 109.32 & 524.89 & 4.007 .83 & 849.48 \\
\hline $\begin{array}{c}\text { Import / Export, } \\
\text { USD } \\
\end{array}$ & \begin{tabular}{|l|}
$62386 \mathrm{M} /$ \\
$53776 \mathrm{M}$ \\
\end{tabular} & \begin{tabular}{|l|}
$261841 \mathrm{M} /$ \\
$283749 \mathrm{M}$ \\
\end{tabular} & \begin{tabular}{|c|}
$326.9 \mathrm{~B} /$ \\
$411 \mathrm{~B}$ \\
\end{tabular} & \begin{tabular}{|l|}
$214637 \mathrm{M} /$ \\
$189714 \mathrm{M}$ \\
\end{tabular} \\
\hline $\begin{array}{c}\text { Exports of goods } \\
\text { and services in \% } \\
\text { of GDP }\end{array}$ & 49.3 & 52.3 & 26.5 & 22 \\
\hline $\begin{array}{c}\text { Added value in } \\
\text { the } \\
\text { manufacturing } \\
\text { industry in the } \\
\text { current rate of } \\
\text { price growth, } \%\end{array}$ & 3.6 & 4.3 & 13.7 & 3.8 \\
\hline \begin{tabular}{|c|} 
Household \\
consumption \\
expenditure in \% \\
of GDP \\
\end{tabular} & 65.3 & 58.5 & 53.09 & 59.8 \\
\hline $\begin{array}{c}\text { Gross capital } \\
\text { accumulation in } \\
\% \text { of GDP } \\
\end{array}$ & 20.4 & -7.9 & -1.8 & 29.3 \\
\hline $\begin{array}{c}\text { Market } \\
\text { capitalization of } \\
\text { companies in \% } \\
\text { of GDP } \\
\end{array}$ & +15.7 & 38.4 & 39.5 & 26.7 \\
\hline $\begin{array}{c}\text { GDP per capita, } \\
\text { USD } \\
\end{array}$ & 2583 & 13823 & 10.608 & 10.512 \\
\hline $\begin{array}{l}\text { Government's net } \\
\text { debt in \% of GDP }\end{array}$ & 75.6 & 51.4 & 17.4 & 22.7 \\
\hline \begin{tabular}{|c|}
$\begin{array}{c}\text { Net outflow of } \\
\text { foreign direct } \\
\text { investment in \% } \\
\text { of GDP }\end{array}$ \\
\end{tabular} & 0.2 & 0.8 & 2.4 & 0.3 \\
\hline \begin{tabular}{|c|} 
Net inflow of \\
foreign direct \\
investment in \% \\
of GDP \\
\end{tabular} & 2.2 & 1.2 & 1.8 & 1.3 \\
\hline \begin{tabular}{|c|} 
Total production \\
of primary energy \\
quadrillion Btu \\
\end{tabular} & 2.3 & 2.3 & 55.9 & 1.2 \\
\hline $\begin{array}{l}\text { Consumption of } \\
\text { primary energy } \\
\text { quadrillion Btu }\end{array}$ & 3.4 & 3.9 & 29.6 & 5.7 \\
\hline $\begin{array}{c}\text { Net energy } \\
\text { imports as a share } \\
\text { of energy use, } \%\end{array}$ & 27.2 & 28.5 & -83.7 & 75.2 \\
\hline
\end{tabular}

Thus, according to the Table 3, Ukraine has some challenges with border protection with respect to its neighboring states, as evidenced by the bottom positions of the State by practically three indexes.

The question that has to be answered is which scenario of the defense capacity development should be chosen to improve the security against possible aggression from the potential aggressor states. When it comes to Russia, there is a special relationship here, as since 2014 the northern neighbor has started to invade 
the territories of Ukraine and in fact is considered to be the greatest threat to the defense capacity of the State. From this perspective we consider several scenarios of strategic axes of defending Ukraine to satisfy the wish of the State to become an independent country. To this end the fundamental characteristics of the AFU development to be singled out and strategies of the defense capacity of the State to be selected based on them. The most favorable indicators and characteristics able to ensure military changes should include the following: improvement of knowledge, skills and experience in military affairs; increase of defense and security expenditures; increase in number of military personnel; growth of bank credit for the defense industry complex development; budgeting for the defense industry complex development; assistance of NATO states.

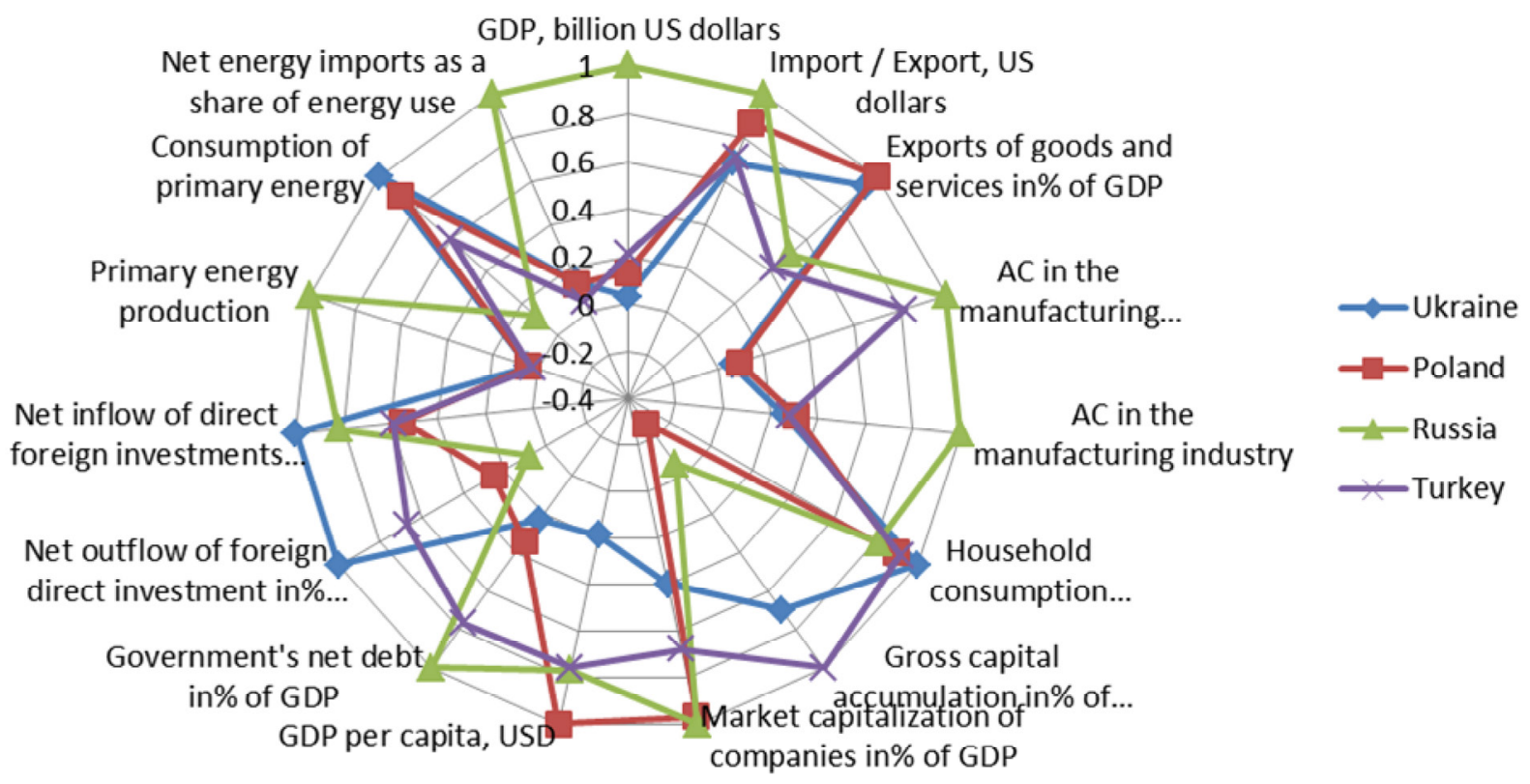

Fig. 1. The petal diagram of macroeconomic development of states: Ukraine, Poland, Russia and Turkey.

Considering the previous indicators that are laid down in the indicators defining the level of defense capacity and clearly characterize the military potential of the State, we will focus on four feasible strategies of the AFU development: reliance on the Land Forces, Air Forces under the progressive development of other branches; reliance on submarines, aircraft carriers and artillery under the progressive development of other branches; reliance on NATO under the progressive development of other branches; reliance on nuclear weapons under the progressive development of other branches. Table 4 shows the possible proportions of ensuring the development strategies of the Armed Forces that derive from strategic defense development programs for 2010-2025 and a survey of experts who are considering probable economic and political situations of its provision. Their modeling scenarios are not limited to the given data. Their modeling scenarios are not limited to the given data. The preliminary graphic data analysis results in a major trend in the AFU development which primarily depends on the increase of knowledge, skills and experience in military affairs and increase of defense and security expenditures. Although such indicators as the increase in number of military personnel, growth of bank credit for the defense industry complex development, budgeting for the defense industry complex development, assistance of NATO states are essential factors that, to some extent, shape any strategy of the AFU development ensuring the progressive development of other branches.
Considering that Table 3 presents the minimum values of the development indicators of the Armed Forces of Ukraine, the best development strategy can be chosen based on the diagram of petals by the criterion indicating that dependence on submarines, aircraft carriers and artillery in the conditions of progressive development of other industries is optimal, Table 5 .

Now let us make a neural network based on the presentation of the multi-layered perceptron structure to compare the results of the AFU development strategies by the two methods, Figure 2-3. First of all, let us form a matrix out of the known input indexes, then normalize and establish boundary parameters for the evaluation of strategies [10].

In Fig. 2 shows the notation: $x=\left\{x^{1}, x^{2}, \ldots, x^{\mathrm{S}}\right\}-$ parameters for the evaluation of strategies; the activation function $\psi(\Sigma)$ of the $i$-layer neuron; $w_{i}$ - synaptic weights.

The mentioned indicators and their variations reflect the selection of possible AFU strategies on a reasonable basis:

1. Strategy - coefficients options are lower by the midpoint of the range - Reliance on NATO;

2. Strategy - coefficients options are mixed exceeding the midpoint of the range - Reliance on submarines, aircraft carriers, and artillery;

3. Strategy - coefficients options approach the maximum point of the range - Reliance on Missile Forces, Air Defense; 
As target indicators, the boundary characteristics of these three indicators for each strategy are selected separately. The run of the neural network is three times, where the convolution for each strategy serves as a good indicator. A comparison of performance indicators makes it possible to assess the prioritization of strategies.

Table 2. The economic condition of the State's defense capacity by MCI.

\begin{tabular}{|c|c|c|c|c|}
\hline Indicator Title & Ukraine & Poland & Russia & Turkey \\
\hline GDP, USD billion & 109.32 & 524.89 & 4007.83 & 849.48 \\
\hline $\begin{array}{c}\text { Resources (dollars) } \\
\text { for the defense and } \\
\text { security and their } \\
\text { percent of GDP }\end{array}$ & $3.648 \mathrm{M}$ & $10 \mathrm{~B}$ & $631 \mathrm{~B}$ & 18.19B \\
\hline Arms Import / & $18 \mathrm{M} /$ & $197 \mathrm{~B} /$ & $34 \mathrm{M} /$ & $410 \mathrm{~B} /$ \\
\hline Export, in USD & $240 \mathrm{M}$ & $3 \mathrm{M}$ & $6.148 \mathrm{~B}$ & $244 \mathrm{M}$ \\
\hline $\begin{array}{c}\text { Export of goods and } \\
\text { services, in \% of } \\
\text { GDP }\end{array}$ & 49.3 & 52.3 & 26.5 & 22 \\
\hline \begin{tabular}{|c|} 
The share of high- \\
technology products \\
export, \%
\end{tabular} & 7.3 & 8.5 & 10.7 & 2 \\
\hline $\begin{array}{c}\text { R\&D expenditure } \\
\text { as a share of GDP, } \\
\%\end{array}$ & 0.6 & 1 & 1.1 & 1 \\
\hline \begin{tabular}{|c|} 
Education \\
expenditures, in \% \\
of GDP
\end{tabular} & 5.87 & 4.91 & 3.8 & 4.4 \\
\hline $\begin{array}{c}\text { Gross fixed capital } \\
\text { formation, in } \% \text { of } \\
\text { GDP }\end{array}$ & 20.4 & -7.9 & -1.8 & 29.3 \\
\hline $\begin{array}{c}\text { Market } \\
\text { capitalization of } \\
\text { companies, in \% of } \\
\text { GDP }\end{array}$ & +15.7 & 38.4 & 39.5 & 26.7 \\
\hline \begin{tabular}{|} 
GDP per capita, \\
USD
\end{tabular} & 2583 & 13823 & 10.608 & 10.512 \\
\hline $\begin{array}{l}\text { Global Firepower } \\
\text { Index }\end{array}$ & 0.5363 & 0.4276 & 0.0841 & 0.2216 \\
\hline $\begin{array}{c}\text { Total strength of } \\
\text { military personnel, } \\
\text { people }\end{array}$ & $\begin{array}{l}182000 / \\
1 \mathrm{M}\end{array}$ & 184650 & 3586128 & 710565 \\
\hline $\begin{array}{c}\text { World } \\
\text { Competitiveness } \\
\text { Index } \\
\end{array}$ & 4.11 & 4.59 & 4.64 & 4.42 \\
\hline $\begin{array}{c}\text { Human } \\
\text { Development } \\
\text { Index, score }\end{array}$ & 0.74 & 0.86 & 0.80 & 0.77 \\
\hline $\begin{array}{l}\text { Missile launcher, } \\
\text { pieces }\end{array}$ & 625 & 240 & 3816 & 418 \\
\hline Battle tank, pieces & 2214 & 1.065 & 20300 & 2446 \\
\hline $\begin{array}{c}\text { Armored vehicle, } \\
\text { pieces }\end{array}$ & 11868 & 2608 & 27400 & 9031 \\
\hline $\begin{array}{l}\text { Artillery arm, } \\
\text { pieces }\end{array}$ & 2971 & 515 & 6436 & 1980 \\
\hline $\begin{array}{c}\text { Aircraft carrier, } \\
\text { pieces }\end{array}$ & 0 & 0 & 1 & 0 \\
\hline Frigate, pieces & 1 & 2 & 9 & 16 \\
\hline Corvette, pieces & 1 & 2 & 78 & 10 \\
\hline Submarine, pieces & 0 & 4 & 62 & 12 \\
\hline $\begin{array}{c}\text { Aircraft total } \\
\text { number }\end{array}$ & 240 & 466 & $3914 / 818$ & 1056 \\
\hline $\begin{array}{c}\text { Helicopter total } \\
\text { number }\end{array}$ & 94 & 227 & $1451 / 511$ & 475 \\
\hline
\end{tabular}

Table 3. The rating of the states according to the Global Firepower Index, according to the Military Capacity Index and the Credit Suisse Institute Index.

\begin{tabular}{|c|c|c|c|c|c|c|}
\hline States & $\begin{array}{c}\text { Military } \\
\text { Capacity } \\
\text { Index }\end{array}$ & $\begin{array}{c}\text { Priority } \\
\text { by the } \\
\text { MCI }\end{array}$ & $\begin{array}{c}\text { Global } \\
\text { Firepower } \\
\text { Index }\end{array}$ & $\begin{array}{c}\text { Priority } \\
\text { by the } \\
\text { GFI }\end{array}$ & $\begin{array}{c}\text { Index } \\
\text { Credit } \\
\text { Suisse, }\end{array}$ & $\begin{array}{c}\text { Priority } \\
\text { by the } \\
\text { Credit } \\
\text { Suisse }\end{array}$ \\
\hline Ukraine & 0.96 & 3 & 0,5363 & 4 & 30 & 4 \\
\hline Poland & 0.70 & 4 & 0,4276 & 3 & 17 & 3 \\
\hline Russia & 1.93 & 1 & 0,0841 & 1 & 2 & 1 \\
\hline Turkey & 1.17 & 2 & 0,2216 & 2 & 10 & 2 \\
\hline
\end{tabular}

Table 4. AFU development strategies

\begin{tabular}{|c|c|c|c|c|c|c|}
\hline Strategies & 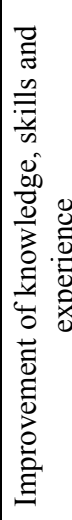 &  & 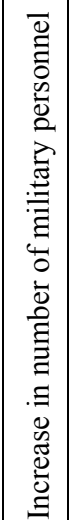 &  & 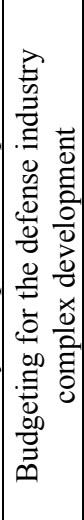 & 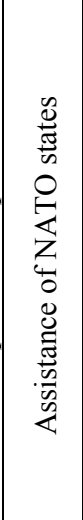 \\
\hline $\begin{array}{l}\text { Reliance on the Land } \\
\text { Forces, Air Forces, \% }\end{array}$ & 50.0 & 70.0 & $30.0 \mid$ & 40.0 & 75.0 & 22.50 \\
\hline $\begin{array}{l}\text { Reliance on submarines, } \\
\text { aircraft carriers and } \\
\text { artillery, \% }\end{array}$ & 90.0 & 80.0 & 40.0 & 50.0 & 70.0 & 45.00 \\
\hline Reliance on NATO, $\%$ & 55.0 & 40.0 & 15.0 & 30.0 & 50.0 & 38.50 \\
\hline $\begin{array}{l}\text { Reliance on nuclear } \\
\text { weapons, \% }\end{array}$ & 65.0 & $85.0 \mid$ & 20.0 & 50.0 & 70.0 & 8.50 \\
\hline
\end{tabular}

Table 5. Criterion for the selection of the best AFU development scenario.

\begin{tabular}{|c|c|}
\hline AFU development strategies & $\begin{array}{c}\text { Selection of the } \\
\text { optimal scenario }\end{array}$ \\
\hline $\begin{array}{c}\text { Reliance on submarines, aircraft } \\
\text { carriers and artillery }\end{array}$ & 1.002 \\
\hline $\begin{array}{c}\text { Reliance on the Land Forces, Air } \\
\text { Forces }\end{array}$ & 1.275 \\
\hline Reliance on NATO & 1.071 \\
\hline Reliance on nuclear weapons & 0.796 \\
\hline
\end{tabular}

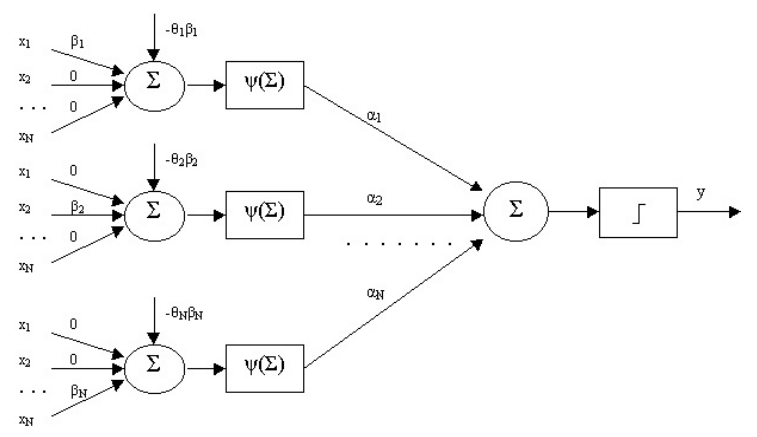

Fig. 2. The overall structure of the neural network [14]. 




Fig. 3. A neural network structure.

The findings of the AFU strategic development should be obtained after the network training Regression, Figure 4.
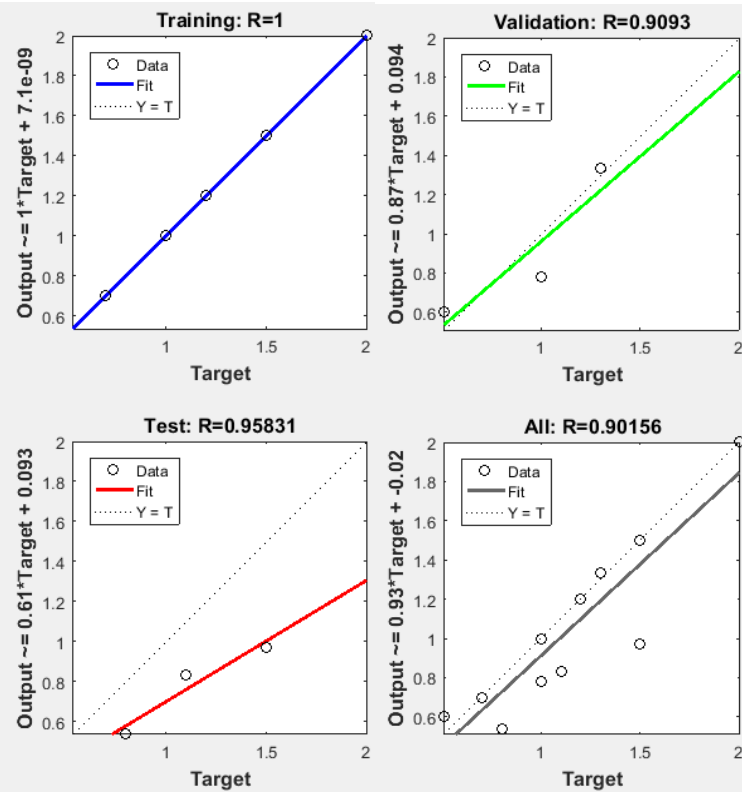

Fig. 4. Outcomes of the neural network training and simulation of the forecasting of the AFU development strategy selection.

The indicators for the AFU that have the following values have been taken as current calculations, namely, Table 6.

Table 6. Strategies for the development of the Armed Forces of Ukraine

\begin{tabular}{|c|c|c|c|}
\hline Index & Strategy 1 & Strategy 2 & Strategy 3 \\
\hline MCI & 1 & 1.56 & 1.63 \\
\hline GFI & 1.39 & 1.39 & 1.58 \\
\hline ICS & 0.6 & 1.05 & 0.75 \\
\hline OUT & 1.0 & 1.33 & 1.32 \\
\hline
\end{tabular}

In the result of the study, the following strategy for the development of the Armed Forces of Ukraine has been received - Reliance on submarines, aircraft carriers, and artillery.

\section{Conclusions}

The outcomes of the defense capacity indexes' evaluation of Ukraine, Poland, Russia, and Turkey indicate some deviations of the states' ratings according to the Military Capacity Index (MCI) as compared to the Global Firepower Index (GFI) and the Credit Suisse (CS) Institute Index with regard to Ukraine and Poland. According to the Global Firepower Index (GFI) Ukraine is inferior to Poland, and according to the Military
Capacity Index (MCI) - on the contrary. This suggests that both states have practically the same level of defense capacity except that Poland is a NATO member state. Regarding the economic status of the defense capacity of Turkey and Russia, Russia has the lead and ranks world second after the USA. Although they also have significant economic problems that, in the long term, will provide Ukraine the possibility with proper planning of the defense capacity and availability of considerable intellectual capital, to reach their level and to ensure the inviolability of the state's borders from possible invasion.

Scenario modeling to select the best AFU development scenario allows you to formulate the best development strategy indicating that reliance on submarines, aircraft carriers, and artillery in the context of the progressive development of other industries is possible but very costly. Therefore, the options of betting on missile troops and Air Defense are preferable, which in terms of indicators has a slight discrepancy.

The outcomes indicate that both methods of the search for the AFU development strategies complement each other and provide an overall picture of the possible directions to achieve a responsible goal related to the defense capacity of the State.

\section{References}

1. Horbulin, V. P.: Strategic planning: solution to national security challenges. NISS, Kyiv (2010)

2. Bohdanovych, V.Yu.: Method of strategic planning formalization in the area of public administration to ensure national security. Str. Pan. 3, 42-53 (2006)

3. Kachynskyi, A.B.: Security, threats and risk: scientific concepts and mathematical methods. Kyiv (2003)

4. Reznikova, O.O., Tsiukalo, V.Yu.: The development of the strategic planning and forecasting system in the area of national security of Ukraine. http://www.niss.gov.ua/articles/1847 (2018). Accessed 05 Feb 2019

5. Reznikova, O.O.: Ensuring the resistance of the State and society to the terrorist threat in Ukraine and in the world. Str. Pr. 3(44), 23-24 (2017)

6. Mozharovskyi, V.M., Hodz', S.V.: Methodical Aspects of the Substantiation of the Manpower of the Armed Forces of the State from the Standpoint of the Prevented Damage Theory. Cyb. and Sys. An. 54(1), 139-151 (2018)

7. Mozharovskyi, V.M., Hodz', S.V.: Mathematical Model of the Substantiation of the Optimal Combat Staff of the Armed Forces of the State from the Standpoint of the Theory of Prevented Damage and with Regard to Economic Review. Cyb. and Sys. An. 54(5), 815-823 (2018).

8. Charlles J.: Hitch, Decision Making for Defense. Science, New York (2004)

9. Grytsenko, A.: Civil-military relations in Ukraine: On the way from Form to substance, NATO Fellowship 
http://www.nato.int/acad/fellow/98-

00/grytsenko.pdf (2000). Accessed 15 Jan 2019

10. Porokhnya V.M.: Expert systems in economy. Zaporizhzhia (1997)

11. World Data Atlas. https://knoema.com/atlas (2018) Accessed 29 Jan 2019

12. Globalfirepower.

https://www.globalfirepower.com/countries-listingeurope.asp (2018). Accessed 20 Jan 2019

13. CreditSuisse. https://www.creditsuisse.com/corporate/en/research/researchinstitute/publications.html (2018). Accessed 28 Jan 2019

14. Subbotin, S.O., Fedorchenko, E.M.: Methodical instructions for the implementation of laboratory works on discipline "Neural Network Design" for students of the training direction 6.050101 "Computer Science" of all forms of study. Zaporizhzhya (2013). 